\title{
SOVEREIGN CREDIT RATINGS AND ASIAN FINANCIAL MARKETS
}

\section{Khansa Pervaiz', Zuzana Virglerová2, Muhammad Asif Khan³ Usman Akbar', József Popp ${ }^{5}$}

\footnotetext{
1 Yanshan University, School of Economics and Management, China, ORCID: 0000-0002-0474-8433, khansapervaiz@outlook.com;

2 Tomas Bata University in Zlín, Faculty of Management and Economics, Czech Republic, ORCID: 0000-0002-79579216, virglerova@utb.cz;

3 University of Kotli, Faculty of Management Sciences, Department of Commerce, Pakistan, ORCID: 0000-00023563-2951, khanasif82@uokajk.edu.pk;

4 Yanshan University, School of Economics and Management, China, ORCID: 0000-0003-2109-546X, usman.akbar@outlook.com;

5 WSB University, Department of Management, Faculty of Applied Sciences, Poland, ORCID: 0000-0003-0848-4591, poppjozsef55@gmail.com.
}

\begin{abstract}
Each region/country seeks to become more efficient to gain the confidence of potential investors. Most of the Asian economies are categorized as emerging markets, where the role of financial markets has even become more intensified to provide financial services to increasing economic and financial activities. Asian financial market has momentously suffered during the Asian, and global financial crisis. The mass destruction was mainly caused due to the mounting uncertainty, which spillover throughout the region, where investors lost their confidence. Considering the pivotal economic role of financial markets, and implications evolve due to sovereign credit rating announcements, this study aims to model the role of sovereign credit rating announcements by Standard and Poor's, and Moody's on financial market development of the Asian region. For 24 Asian countries/regions, we perform a regression analysis on sovereign credit rating changes based on financial market development index and its factors. The findings of Driscoll Kraay's robust estimator reveals that improvement in sovereign credit rating score enhances the financial market development in the region. Moreover, we applied several robustness checks, such as alternative estimators, alternative measures, and three sub-dimensions of financial market development. According to the findings from these robustness checks, the positive impact of sovereign credit ratings on financial market development in the region is robust. Unlike prior literature (which is confined to the event study approach), this study utilizes the historical grades to establish the relationship under the standard error clustering approach. Due to the diversity of investors' speculations, we propose a micro-level extension of the present model to overcome a difference in country policy.
\end{abstract}

Keywords: Sovereign credit ratings, financial market development, panel data models, Standard and Poor's, Moody's, Asia.

JEL Classification: E44, F3, C23, G15.

APA Style Citation: Pervaiz, K., Virglerová, Z., Khan, M. A., Akbar, U., \& Popp, J. (2021). Sovereign Credit Ratings and Asian Financial Markets. E\&M Economics and Management, 24(1), 165-181. https://doi.org/10.15240/tul/001/2021-1-011

\section{Introduction}

Sovereign credit rating (SCR) is an important utensil to judge the creditworthiness and competitiveness of an economy, which facilitates the potential investors to gain confidence in making investment decisions across the globe (Yang et al., 2019). It serves as a "credit passport" to investors to gain useful 
information about the financial markets in terms of dependable share prices, trim financial obstacles along with provocative effective investment (Mclean et al., 2012; Xu et al., 2019; Zhao et al., 2020). Higher SCR signals a relatively higher performance of companies/ economies (Cubas-Díaz et al., 2018). The efficient market hypothesis holds that financial markets are sensitive to new information, where a piece of information is translated into security prices, depending upon the development of such markets. Literature has established that SCR announcements influence the prices of financial securities (Kliger et al., 2000; Poon et al., 2008). Therefore, changes in the SCR encourage both, the stock market, and the country risk - such a change provides borrowers and lenders with an indication of a corporation's risk profile, enabling them to determine the risk premiums. SCR improves the capability of emerging economies to capture the international market by attracting foreign investments (Andritzky et al., 2007; Bissoondoyal-Bheenick et al., 2015; Dvorský et al., 2019; Gavurová et al., 2020; Khursheed et al., 2018; Kim et al., 2008; Hussain et al., 2018). Most of the referred studies examine the short-term effects of such announcements on security prices using event study approach and find that the financial market is sensitive to SCR announcements, where investors differently react to the new information, depending upon the direction (positive/negative) and magnitude of change (Böninghausen et al., 2015; Bremer et al., 2002; Creighton et al., 2007; Hu et al., 2016; Jorion \& Zhang, 2007; Klimavičiena, 2011; Li et al., 2019; Michaelides et al., 2012; Norden \& Weber, 2004; Pukthuanthong-Le et al., 2007; Subaşı, 2008).

Importantly, the event study methodology provides input for short-run investment decisions, where strategic investment decisions demand a more careful analysis of the implication of changes in SCR and specifically in Asian markets. Although, event study approach guides short-term investment decision, yet, the findings of event study are conflicting (Li et al., 2019). Li et al. (2019) is an exception, which captures the short- and long-run asymmetric impact of SCR but this is also on the European financial market using the nonlinear framework (Shin et al., 2014). No doubt that this is an important effort that extends the literature on the paradigm of long-run asymmetric analysis in SCR-financial market connection, yet this framework overlooks some of the critical diagnostic issues (i.e., crosssectional dependence, heteroskedasticity, and serial correlation) embedded to panel data estimation.

This paper aims to determine the role of SCR in the financial market development of Asian economies, which is found scarce. The global financial crisis spread through trade and financial channels hit the Asian economy and caused a simultaneous global slowdown. The huge uncertainty in the future of the Asian economy has led to the recovery of the financial system, which has promoted this research. We use Driscoll Kraay's covariance matrix (Driscoll et al., 1998) to investigate the impact of SCR announcements on the development of financial markets in 24 Asian economies/regions from 1990 to 2018. The paper is organized as follows: the literature review brings a critical review of another international research that focuses on the topic of SCR. The following part deals with the materials and methods used to fulfill the aim of the paper. The next part outlines the empirical results and discussion of the results. The paper is concluded with a summary of the main results and limitations of the paper.

\section{Theoretical Background}

The three main rating agencies (Moody's, Standard and Poor's and Fitch) provide credit ratings based on economic, social, and political factors (Chen et al., 2016; Chodnicka-Jaworska, 2017). Many pieces of research have confirmed the importance of SCR for the economic development of countries (e.g. Afonso et al., 2011; Gärtner et al., 2011; Teixeira et al., 2014). SCR influences a borrowing cost in international markets not only for the sovereign state but also for the financial institution active in that state (Drago \& Gallo, 2017). Chen et al. (2016) state that SCR has an impact on investment decisions and economic growth. Adelino and Ferreira (2016) show the dependence of the rating score of banks on the SCR. Banks are affected if the SCR is downgraded. Altavilla et al. (2017) pointed out a strong effect of SCR on bank lending and domestic firm in the case of banks from the Eurozone. According to Gilchrist et al. (2014), if investors estimate the high risk of the country, they demand higher interest rates. Fitch (2014) points the higher importance of SCR during the crisis. The effect of financial 
crises on SCR has been analyzed by Amstad and Packer (2015).

A country's financial history, liabilities and current assets are used to calculate SCR and are subject to risk assessment and provide investors with a fair assessment. The downgrade of sovereign ratings in neighboring countries during the crises affects stock markets (Muharam et al., 2019). Returns of countries effected by crisis effects due to changes in the rating of other countries, suggesting that SCR changes operate as a further avenue of international financial contagion during the Asian financial crises is confirmed by ( $\mathrm{Li}$ et al., 2008). A country's financial stability for the long run is largely determined by a mixture of current account balances, foreign debt level, the stability of foreign exchange, current account balances, and international liquidity (Gospodarchuk \& Suchkova, 2019; Lu et al., 2020). In the long run, financial, economic, and political variables affect the stock market of Turkey (Sari et al., 2013). Whereas only political and financial risk variables are having an impact in the short run. After the financial crisis, liquidity risk was considered in the model of European banks by the characteristics of banks (such as capital, size, and business model). Experimental results show that the core banking business, based on the maturity transformation process, is the most sensitive to liquidity risk (Galletta et al., 2019). Legal institutional environment is closely connected to the banking system performances and thus sovereign credits ratings as the results from the study Kao et al. (2019) show.

Another research investigated the dynamic relationship between liquidity and credit risk in the Italian debt market through the Eurozone crisis and succeeding European Central Bank interferences - findings reveal that credit risk is a major driver of market liquidity (Pelizzon et al., 2016; Heller \& Warzala, 2019). De Souza Murcia et al. (2013) studied the effect of SCR in the listed public companies' stock prices in the Brazilian market and reveals that SCR declaration has information content because it will affect stock returns and lead to abnormal returns, especially when they carry the bad news to the market through the observation sample of 242 listed companies through event research. This view is largely due to the belief that the country's ratings do provide new information for financial markets. Bissoondoyal-Bheenick et al. (2015) witnesses that the upgrade of SCR has significantly affected the stock market. Rating improvement usually occurs during the unification of financial markets, while rating decline occurs during periods of a market downturn.

Specifically, Huang et al. (2018) examine how the downgrade of bond ratings took into account the price of China's common stock and suggested that the ratings given by rating agencies have information value and that the market effectively responded to such announcements. The strength-based Eurozone master spread model determines the liquidity pricing effect in the spread between bonds issued by German institutions and their sovereign counterparts. The authors found that liquidity effects accounted for a considerable share of spread fluctuations (Monfort et al., 2013). Only the Chinese stock market is politically risk-sensitive proved by wide research on BRICs countries (Hammoudeh et al., 2013). Asian stock exchange is closely connected to the U.S. stock exchange and other world financial markets resulting in global spillover effect that impacts country's credit ratings (Gulzar et al., 2019).

The impact of SCR on corporate borrowing goes beyond the sovereign rating process. Research on the impact of sovereign caps on company ratings remains important in countries where capital account restrictions still exist and countries with high political risks (Borensztein et al., 2013). Another research stated that the joint impact of the announcement of rating on pairwise correlation is insignificant (Sensoy et al., 2016).

In addition, the influence of individual rating agencies shows that Moody's announcements are more influential than other announcements. Their findings indicate that due to changes in sovereign ratings, shocks within a single country generally do not spread. In other words, the area is less affected by systemic risks. According to Ismailescu et al. (2010), by using a sample of 22 emerging markets from 2001 to 2009 , positive rating announcements are more likely to affect other emerging markets than negative announcements. Evidence from the European debt market witnessed the significant impact of sovereign rating news from 1995 to 2010 (Afonso et al., 2011).

Around the Asian financial crisis, in the region on the Asia Pacific, it was observed that the results of different sovereign rating 
announcements exposed the spillover effects on the stock and currency markets (Treepongkaruna et al., 2012). They found that the currency and stock markets reacted significantly differently to rating announcements. Compared to the money market, the stock market responded more to rating news. They found clear evidence that the rating event had a significant and asymmetric impact on the second moment of asset market returns under normal market conditions, while the national market aspect affected the rating footprint during the financial crisis. Both positive and negative announcements of bond and stock prices change on the "final" route, even if the changes are small (Endress, 2018). Li et al. (2019) is the exception which departs from the traditional even-study approach in investigating the SCRfinancial market development connection using asymmetric modeling (Shin et al., 2014) and found the presence of nonlinearities translated by SCR announcement (Standard and Poor's, and Moody's) to stock market deployment in the European region.

Drawn on the premises of conflicting literature, short-term premia of event study approach, and limitations associated with econometric estimator used in related studies, the research question is drawn, what may be the impact of sovereign credit ratings on the financial market development in the Asian region? To empirically answer this question, this study attempt to investigate the impact of SCR announcements on Asian financial market development, using robust standard error clustering estimators. The choice of Asian region is led by 1) the several unpleasant financial events within the region or across the globe which substantially infected the financial markets ( $\mathrm{Li}$ et al., 2008; Murcia et al., 2013; Treepongkaruna et al., 2012). These events include the global financial crisis (also called the sub-prime mortgage crisis), and the Asian financial crisis. The global financial crisis refers to the period of extreme stress in global financial markets and banking systems between mid2007 and early 2009, during which a downturn in the U.S. housing market was a catalyst for a financial crisis that spread from the United States to the rest of the world through linkages in the global financial system, where Asian economies have suffered immensely. While the Asian financial crisis was a period of the financial crisis that gripped much of East Asia and Southeast Asia beginning in July 1997 and raised fears of a worldwide economic meltdown

\section{Fig. 1: A comparison of financial market development pattern in Europe and Asian}

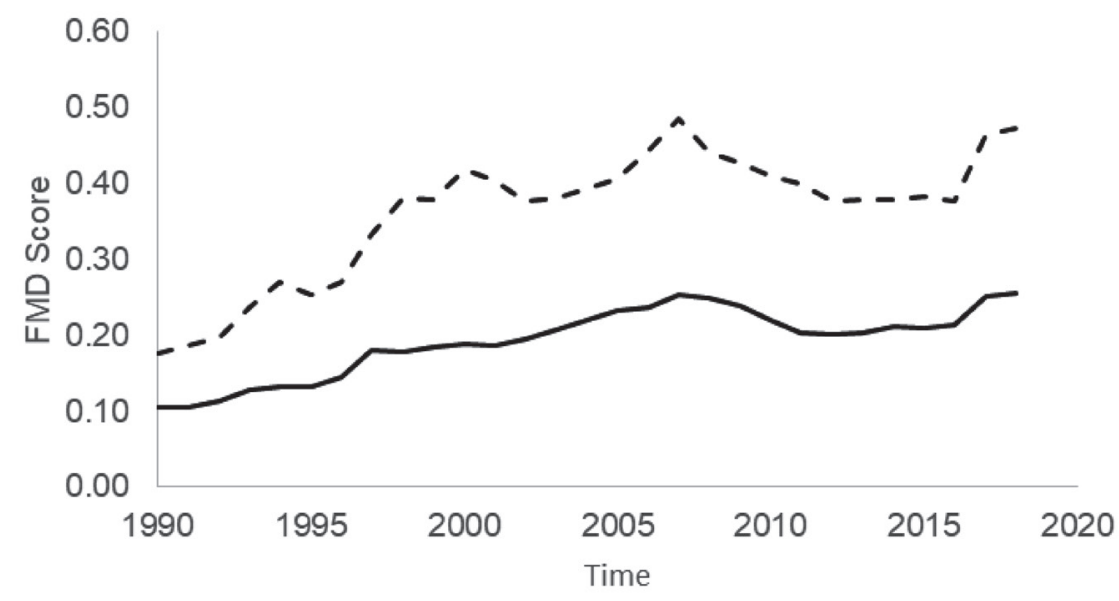

Asia - - Europe 
due to financial contagion. Another reason to choose the Asian region is its financial market cadre that is relatively less developed compared to the European region ( $\mathrm{Li}$ et al., 2019). The scenario is illustrated in Fig. 1, where the blue curve shows the financial market development score for the European region, while the orange curve shows the same for the Asian region (average of 24 economies/territories included in estimation). The financial market development score and historical patterns in both the region illustrate that Asia is low relative to counterpart. This may be underpinned by the middle and low-income cadre of most of the economies of the region as well as low regulations pertaining to the financial markets. The low performance can also be linked to the global financial crisis, in general, and the Asian financial crisis in particular, where the financial sector suffered most.

On the other front, the global financial crisis had hit Asian economies with unexpected speed and force (Keat, 2009). The global financial crisis led to a synchronized global slowdown starting in the second half of 2008, which transmitted through trade and financial channels, particularly in those Asian economies with strong links to international markets (RuizBrunschwig et al., 2011). The impact of the crisis, however, differed among economies depending on the degree of dependency to external demand and credit, where, the Republic of Korea, Thailand, Malaysia, Philippines, China, and India as well as many of the Southeast Asian economies, experienced a marked slowdown in export demand that had important spillover effects into the rest of the economy (Ruiz-Brunschwig et al., 2011). There remains significant uncertainty in the future for Asian economies that causes the financial system to recover slowly relative to Europe. While crossborder spillovers led to the severe underpricing of various types of assets in Asia, the particular illustration comes from an examination of the financial market spillovers from the West to Asia during the global financial crisis (Filardo, 2011). The above description motivates the present study to consider the Asian region as a sample for potential analysis.

\section{Research Objective, Methodology, and Data}

Precisely, this study investigates the impact of SCR announcements on the financial market development of 24 Asian economies/territories (selected subject to data availability) from 1990 to 2018, using Driscoll Kraay's covariance matrix (Driscoll et al., 1998) that is robust in clustering standard error. The list of countries/ territories included in the analysis is annexed in Tab. A1.

\subsection{Variables and Data}

Aligned with Li et al. (2019), the study utilizes financial market development index (FD_FM) - dependent variable, for which data that is compiled from IMF Strategy, Policy, and Review Department. The index comprises financial markets access (FD_FMA), depth (FD_FMD), and efficiency (FD_FME). FD_FMA compiles data on "percent of market capitalization outside of top 10 largest companies and total number of issuers of debt (domestic and external, nonfinancial and financial corporations) per 100,000 adults". FD_FMD compiles data on "stock market capitalization to GDP, international debt securities of government to GDP, and total debt securities of financial and nonfinancial corporation to GDP". FD_FME compiles data on "stock market turnover ratio (stocks traded to capitalization)". The numeric values assigned by the department range between $0-1,0$ shows the least developed financial markets and 1 document remarkable development of the sector. The index is rescaled to 100 for interpretation purposes.

SCR is independent variable, which reflects the creditworthiness of a country to repay its debt obligations as they come due. The weight ranges between $0-100$, the highest score acknowledges the low default risk of a country, while the lowest score makes it exposed to default risk. SCR grades are obtained from Standard and Poor's (SCRS) and Moody's (SCRM) periodical outlooks and numeric weights are assigned based on trading economics benchmark (Tab. A2). The Fitch SCR are not included in the estimation, because those are identical to that of Standard and Poor's numeric scores. The description slightly differs, while numeric scores are alike.

Economic growth (E.G.) is measured as the natural logarithm of per capita GDP, Trade Openness (TRO) is a sum of exports, and imports proportionate to GDP, inflation (INF) is represented by a consumer price index, banking development (D.C.) is denoted by domestic credit to the private sector as to GDP, 


\section{Tab. 1: Descriptive statistics}

\begin{tabular}{l|c|c|c|c|c}
\multicolumn{1}{c|}{ Variable } & Obs & Mean & Std. dev. & Min & Max \\
\hline FD_FM & 696 & 3.352 & 0.921 & 0 & 4.503 \\
\hline$F D \_F M D$ & 696 & 3.256 & 1.039 & 0 & 4.533 \\
\hline FD_FMA & 696 & 2.88 & 1.728 & -2.632 & 4.605 \\
\hline FD_FME & 696 & 3.029 & 1.458 & -1.809 & 4.605 \\
\hline$S C R S$ & 696 & 4.03 & 0.404 & 2.303 & 4.605 \\
\hline$S C R M$ & 696 & 4.025 & 0.382 & 2.708 & 4.605 \\
\hline$E G$ & 696 & 9.599 & 1.166 & 6.852 & 11.749 \\
\hline$I N V$ & 696 & 3.191 & 0.269 & 2.367 & 4.055 \\
\hline$I N F$ & 696 & 1.161 & 1.24 & -4.092 & 7.538 \\
\hline$T R O$ & 696 & 4.267 & 0.663 & 2.561 & 6.041 \\
\hline$D C$ & 696 & 4.279 & 0.701 & 2.148 & 5.981 \\
\hline
\end{tabular}

and investment (INV) is proxied by gross fixed capital formation ratio to GDP. The data for E.G., TRO, INF, DC, and INV are also sourced from WDI. All the variables are transformed into a natural logarithm for efficient estimation. The descriptive statistics of all variables are provided in Tab. 1. We excluded some countries due to missing data (Afghanistan, Armenia, Bangladesh, Bhutan, Brunei, Cambodia, Maldives, Myanmar, Nepal, North Korea,
Palestine, Sri Lanka, East Timor, Georgia, Iran, Iraq, Kyrgyzstan, Laos, Macao, Syria, Taiwan, Tajikistan, Turkmenistan, Uzbekistan, Yemen).

\subsection{Econometric Specification}

Following Li et al. (2019) our baseline panel fixed effect model is specified in the following formula:

$$
y_{i t}=x_{i t} \theta+\varepsilon_{i t}
$$

\section{Tab. 2: First and second-generation unit-root rest results}

\begin{tabular}{|c|c|c|c|c|}
\hline Variable & LLC level & Remarks & CIPS level & Remarks \\
\hline$F D \_F M$ & $-5.44^{\star * \star}$ & Yes & $-2.73^{* * *}$ & Yes \\
\hline$F D \_F M D$ & $-4.98^{\star * *}$ & Yes & $-2.49^{* * *}$ & Yes \\
\hline$F D \_F M A$ & $-5.29^{\star \star *}$ & Yes & $-2.66^{\star * *}$ & Yes \\
\hline$F D \_F M E$ & $-4.59^{* * *}$ & Yes & $-2.59^{* * *}$ & Yes \\
\hline SCRS & $-2.28^{* *}$ & Yes & $-2.16^{* *}$ & Yes \\
\hline SCRM & $-7.37^{* * *}$ & Yes & $-3.85^{\star * *}$ & Yes \\
\hline$E G$ & $-7.09^{\star \star *}$ & Yes & $-3.95^{\star * *}$ & Yes \\
\hline INV & $-9.82^{\star * *}$ & Yes & $-4.37^{* * *}$ & Yes \\
\hline INF & $-8.72^{\star \star *}$ & Yes & $-4.56^{* * *}$ & Yes \\
\hline TRO & $-9.11^{\star \star *}$ & Yes & $-4.34^{* \star *}$ & Yes \\
\hline$D C$ & $-7.51^{* * *}$ & Yes & $-4.02^{* * *}$ & Yes \\
\hline
\end{tabular}

Source: own

Note: LLC = Levin-Lin-Chu unit-root test; CIPS = Pesaran's unit-root test with cross-sectional independence. 
where the dependent variable $y_{i t}$ is $F D_{-} F M, x_{i t}$ is a $(\mathrm{K}+1) \times 1$ vector of independent variables $\left(S C R_{i t}, I N V_{i t}, T R O_{i t}, E G_{i t}, I N F_{i t}\right.$, and $\left.D C_{i t}\right)$ whose first element is 1 and $\theta$ is $(\mathrm{K}+1) \times 1$ vector of the unknown coefficient. $i$ denotes the cross-sectional units ("individuals") and $t$ denotes time. All the acronyms used in this section are defined in section 2.1. The estimator used by $\mathrm{Li}$ et al. (2019) is applicable in the case of unique integration order, where the underlying variables are found having mixed integration order (level, and first difference), which does not hold in the present case. Tab. 2 incorporates both first- and second-generation panel unit-root test results, which shows that all the variables are stationary at level. Therefore, continuing with $\mathrm{Li}$ et al. (2019) asymmetric modeling is not suitable.

In addition, Li et al. (2019) do not account for common panel data issues of crosssectional dependence, heteroskedasticity, and serial correlation. Therefore, the scenario calls for a robust estimator capable of dealing with standard error clustering issues. We first estimate the panel fixed effect model, and test its diagnostic properties, which reveal that the estimator violates the standard assumptions. Thus, we opt Driscoll Kraay's covariance matrix estimator (Driscoll et al., 1998), which overcomes the shortcomings attributed to panel fixed effect estimator, particularly, provided that the residuals are independently distributed, standard errors which are obtained by the aid of this estimator are consistent even if the residuals are heteroscedastic (Hoechle, 2007). Driscoll Kraay's fixed-effects estimator is implemented in two steps. In the first step all model variables $z_{i t} \in\left\{y_{i t}, x_{i t}\right\}$ are within-transformed as follows:

$$
\tilde{z}_{i t}=z_{i t}-\bar{z}_{i t}+\overline{\bar{Z}}_{i t}
$$

where:

$$
\bar{z}_{i t}=T_{i}^{-1} \sum_{t=t i_{1}}^{T_{i}} Z_{i t} \text { and } \overline{\bar{z}}_{i}=\left(\sum_{T_{i}}\right)^{-1} \sum_{i} \sum_{t} Z_{i t}
$$

Recognizing that the within-estimator corresponds to the OLS estimator of the second step than estimates the transformed regression model in the following equation by Driscoll Kraay's standard error.

$$
\tilde{y}_{i t}=\tilde{x}_{i t}^{\prime} \theta+\tilde{\varepsilon}_{i t}
$$

\section{Results}

For 24 countries/regions, we perform a regression analysis on SCR changes based on FD_FM and its factors. Regression results include cross-sectional observations of each explanatory variable based on autocorrelation, grouped heteroscedasticity using a modified Wald test, and adjusted FD_FM $\mathrm{R}^{2}$ (including three factors), shown in Tab. 3. As can be seen, the adjusted $R^{2} s$ are not high, FD_FMA has a relatively lower adjusted $R^{2}$, and the highest one is of the FD_FMD (i.e., 0.075), which is significant. This demonstrates that the regression variables do not have variations in the SCR. SCR has a direct and strong impact on the performance of financial markets except for FD_FMA, all other factors are above $50 \%$. The INV, INF, E.G., and D.C. coefficients of all Asian countries are appeared negative except of TRO which has better impact with FD_FMD (i.e., 0.163).

Considering the cross-sectional dependence, we can conclude that there is sample evidence that the sampled Asian countries should go hand in hand with the variables that promote growth. This indicates that there are differences between countries in the literature. For example, the selected Asian countries can be studied separately, thereby stimulating the need for applying time-series estimation. Secondly, despite the formation of the Asian group of countries, if one economy follows the sequence after another, their integration may be harder to achieve. Tab. 3 shows that using the baseline panel fixed effect model, SCRS positively explains the FD_FM and its three components (access, depth, and efficiency). One standard deviation positive change in SCRS brings about 0.52 standard deviation improvement in financial market development.

In contrast, the same change in SCRS translates $0.42,0.84,0.76$ standard deviation improvement in financial market access, depth, and efficiency, respectively. This implies that SCRS helps citizens of Asian economies access the financial services offered within each economy, and it also deepens the financial services and enhances their efficiency. Among control variables, TRO appears to be a stimulator to financial market development across all models. In contrary, INV, E.G., INF, and D.C. have negatively impacted financial market development, but coefficients are not consistent across all models. Although the findings are compatible with the intuition, the bottom part of Tab. 3 shows diagnostic statistics, which calls for estimating a robust estimator to correct/ 


\section{Tab. 3: Fixed effect regression results}

\begin{tabular}{|c|c|c|c|c|}
\hline \multirow{2}{*}{ Variables } & (1) & (2) & (3) & (4) \\
\hline & $F D \_F M$ & $F D \_F M A$ & FD_FMD & $F D \_F M E$ \\
\hline \multirow{2}{*}{$\operatorname{SCRS}_{\text {it }}$} & $0.519^{* * *}$ & $0.422^{* * *}$ & $0.844^{* * *}$ & $0.757^{* * *}$ \\
\hline & $(0.115)$ & $(0.107)$ & $(0.144)$ & $(0.191)$ \\
\hline \multirow{2}{*}{$I N V_{i t}$} & $-0.199^{* *}$ & -0.041 & -0.124 & $-0.229^{*}$ \\
\hline & $(0.082)$ & $(0.076)$ & $(0.102)$ & $(0.136)$ \\
\hline \multirow{2}{*}{$T R O_{i t}$} & $0.127^{* * *}$ & $0.069^{* *}$ & $0.163^{* * *}$ & $0.148^{* * *}$ \\
\hline & $(0.034)$ & $(0.032)$ & $(0.043)$ & $(0.057)$ \\
\hline \multirow{2}{*}{$E G_{i t}$} & -0.026 & -0.017 & $-0.067^{\star *}$ & -0.025 \\
\hline & $(0.022)$ & $(0.020)$ & $(0.028)$ & $(0.037)$ \\
\hline \multirow{2}{*}{$I N F_{i t}$} & -0.030 & -0.011 & $-0.049^{* *}$ & -0.052 \\
\hline & $(0.019)$ & $(0.018)$ & $(0.024)$ & $(0.032)$ \\
\hline \multirow{2}{*}{$D C_{i t}$} & $-0.060^{*}$ & $-0.085^{\star \star *}$ & $-0.074^{*}$ & -0.033 \\
\hline & $(0.034)$ & $(0.031)$ & $(0.042)$ & $(0.056)$ \\
\hline \multirow{2}{*}{ Constant } & $1.890^{* * *}$ & $1.556^{\star * *}$ & 0.569 & 0.529 \\
\hline & $(0.565)$ & $(0.522)$ & $(0.706)$ & $(0.938)$ \\
\hline Obs. & 696 & 696 & 696 & 696 \\
\hline Cross-sections & 24 & 24 & 24 & 24 \\
\hline Adj. R-squared & 0.061 & 0.040 & 0.075 & 0.041 \\
\hline Fixed effect & Yes & Yes & Yes & Yes \\
\hline \multicolumn{5}{|l|}{ Post estimations } \\
\hline $\begin{array}{l}\text { Pesaran's test of } \\
\text { cross-sectional independence }\end{array}$ & $34.122^{* \star *}$ & $19.535^{\star * *}$ & $42.65^{\star \star *}$ & $15.72^{* \star *}$ \\
\hline Wooldridge F (autocorrelation) & $243.61^{* * *}$ & $49.42^{\star \star *}$ & $173.29^{\star \star *}$ & $59.319^{* * *}$ \\
\hline $\begin{array}{l}\text { Modified Wald test } \\
\text { (groupwise heteroskedasticity) }\end{array}$ & $5,007.04^{* * *}$ & $10,957.72^{* * *}$ & $9,830.23^{* * *}$ & $120,000^{* * *}$ \\
\hline
\end{tabular}

Source: own

Note: Standard errors are in parenthesis; ${ }^{* * *} p<0.01,{ }^{* *} p<0.05,{ }^{*} p<0.1$.

cluster these issues. In particular, Pesaran's cross-sectional independence test, Wooldridge F-test for autocorrelation, and Modified Wald test for groupwise heteroskedasticity have shown presence diagnostic problems with the estimated fixed-effect model. Thus, we proceed for robust standard clustering estimator.

Tab. 4 incorporates the robustness results using alternative estimators such as FGLS (Beck \& Katz, 1995), White (1980), Rogers (1993), Fama and MacBeth (1973), and Driscoll Kraay (1998), such estimators helped in correcting/clustering the standard error issues which were diagnosed/reported in Tab. 3. All these estimators show a significant and positive impact of SCRS on FD_FM (being highest with FGLS with 0.681 , while all other also above $50 \%$ ) in the Asian region. Also, with FGLS, control variable INV appears positive, and the dependent variable FD_FM is higher in response to TRO using Rogers' (i.e., 0.127). The E.G., INF, and D.C. seem negative with all estimators with different magnitude. Thus, overall findings are robust and consistent with 


\begin{tabular}{|c|c|c|c|c|c|}
\hline \multirow{3}{*}{ Variable } & (1) & (2) & (3) & (4) & (5) \\
\hline & $F D \_F M$ & $F D \_F M$ & $F D \_F M$ & $F D \_F M$ & $F D \_F M$ \\
\hline & FGLS & White & Rogers & Fama-MacBeth & Driscoll Kraay \\
\hline \multirow{2}{*}{$S_{C R S}{ }_{i t}$} & $0.681^{* * *}$ & $0.519^{* * *}$ & $0.519^{* * *}$ & $1.146^{* * *}$ & $0.519^{* * *}$ \\
\hline & $(0.037)$ & $(0.214)$ & $(0.115)$ & $(0.093)$ & $(0.097)$ \\
\hline \multirow{2}{*}{$I N V_{i t}$} & 0.028 & $-0.199^{\star}$ & $-0.199^{* *}$ & $-0.388^{* * *}$ & $-0.199^{*}$ \\
\hline & $(0.051)$ & $(0.108)$ & $(0.082)$ & $(0.132)$ & $(0.115)$ \\
\hline \multirow{2}{*}{$T R O_{i t}$} & $0.120^{\star \star *}$ & $0.127^{*}$ & $0.127^{\star \star *}$ & $0.093^{* *}$ & $0.127^{\star \star *}$ \\
\hline & $(0.020)$ & $(0.073)$ & $(0.034)$ & $(0.040)$ & $(0.029)$ \\
\hline \multirow{2}{*}{$E G_{i t}$} & $-0.033^{* * *}$ & -0.026 & -0.026 & -0.053 & $-0.026^{*}$ \\
\hline & $(0.012)$ & $(0.034)$ & $(0.022)$ & $(0.040)$ & $(0.014)$ \\
\hline \multirow{2}{*}{$I N F_{i t}$} & $-0.037^{* * *}$ & -0.030 & -0.030 & -0.041 & $-0.030^{*}$ \\
\hline & $(0.013)$ & $(0.021)$ & $(0.019)$ & $(0.035)$ & $(0.017)$ \\
\hline \multirow{2}{*}{$D C_{i t}$} & $-0.123^{* * *}$ & -0.060 & $-0.060^{*}$ & -0.034 & $-0.060^{\star *}$ \\
\hline & $(0.021)$ & $(0.083)$ & $(0.034)$ & $(0.038)$ & $(0.026)$ \\
\hline \multirow{2}{*}{ Constant } & $1.285^{\star * \star}$ & 1.890 & $1.890^{* * *}$ & 0.247 & $1.890^{* * *}$ \\
\hline & $(0.245)$ & $(1.276)$ & $(0.565)$ & $(0.767)$ & $(0.420)$ \\
\hline Obs. & 696 & 696 & 696 & 696 & 696 \\
\hline Cross-sections & 24 & 24 & 24 & 24 & 24 \\
\hline R-squared & & 0.061 & 0.061 & 0.430 & \\
\hline
\end{tabular}

Note: Standard errors are in parenthesis; ${ }^{* * *} p<0.01,{ }^{* *} p<0.05,{ }^{*} p<0.1$.

the main results, which makes our results reported in Tab. 3 valid. Hence, SCRS helps Asian economies obtain financial services provided by each economy, thereby improving efficiency and deepening financial services.

The study performs second robustness using alternative measure SCRM. Tab. 5 shows the results of Driscoll Kraay's robust estimator, which produces consistent results to SCRS, except for a slight variation in the explanation's magnitude. Under this specification, the SCRM explains FD_FM by 0.603 , comprised of the FD_FMA with 0.43 , FD_FMD by 0.57 , and FD_FME by 0.51 . TRO is positively driving the FD_FM, which needs to be improved further to attract foreign capital flows to the Asian region. This robustness also shows E.G., INF, and D.C. negative. The explanation is substantial to count as valuable input for policy implications to Asian equity markets. These exciting findings provide useful insights into investment and economic growth regulations. Besides, these results confirm the importance of considering necessary controls when studying other factors.

To be consistent, the study checks third robustness using an alternative estimator (FGLS, and Driscoll Kraay's) with subdimensions of FD_FM, where SCRS is taken as an explanatory variable. Interestingly, the findings are consistent with the main model. Under FGLS, one standard deviation upward movement in SCRS explains FD_FMA with 0.13 , FD_FMD with 1.05 , FD_FDE with 0.75 respectively in model $1-3$. Similarly, under Driscoll-Kraay estimator, the upward movement in SCRS boosts FD_FMA with 0.42, FD_FMD with 0.84 , and FD_FDE with a 0.76 standard deviation respectively in model $4-5$. This 
Tab. 5: Robustness: alternative measure (SCRM)

\begin{tabular}{|c|c|c|c|c|}
\hline \multirow{2}{*}{ Variable } & (1) & (2) & (3) & (4) \\
\hline & $F D \_F M$ & FD_FMA & $F D \_F M D$ & $F D \_F M E$ \\
\hline$S C R M_{i t}$ & $\begin{array}{c}0.603^{\star * *} \\
(0.061)\end{array}$ & $\begin{array}{c}0.433^{* * *} \\
(0.079)\end{array}$ & $\begin{array}{c}0.565^{\star * *} \\
(0.094)\end{array}$ & $\begin{array}{c}0.510^{* * \star} \\
(0.092)\end{array}$ \\
\hline$I N V_{\text {it }}$ & $\begin{array}{c}-0.216^{*} \\
(0.119)\end{array}$ & $\begin{array}{l}-0.041 \\
(0.112)\end{array}$ & $\begin{array}{l}-0.111 \\
(0.122)\end{array}$ & $\begin{array}{l}-0.220 \\
(0.190)\end{array}$ \\
\hline$T R O_{i t}$ & $\begin{array}{c}0.129^{* * *} \\
(0.032) \\
\end{array}$ & $\begin{array}{c}0.069^{* * *} \\
(0.022)\end{array}$ & $\begin{array}{c}0.161^{* * *} \\
(0.047)\end{array}$ & $\begin{array}{c}0.146^{* * *} \\
(0.046) \\
\end{array}$ \\
\hline$E G_{i t}$ & $\begin{array}{c}-0.034^{*} \\
(0.020)\end{array}$ & $\begin{array}{l}-0.016 \\
(0.022)\end{array}$ & $\begin{array}{l}-0.057 \\
(0.036)\end{array}$ & $\begin{array}{l}-0.018 \\
(0.035)\end{array}$ \\
\hline$I N F_{i t}$ & $\begin{array}{l}-0.025 \\
(0.020) \\
\end{array}$ & $\begin{array}{l}-0.008 \\
(0.014)\end{array}$ & $\begin{array}{c}-0.045^{\star} \\
(0.026)\end{array}$ & $\begin{array}{c}-0.048^{*} \\
(0.025)\end{array}$ \\
\hline$D C_{i t}$ & $\begin{array}{c}-0.071^{* *} \\
(0.027)\end{array}$ & $\begin{array}{c}-0.093^{* * *} \\
(0.028)\end{array}$ & $\begin{array}{c}-0.088^{* *} \\
(0.043)\end{array}$ & $\begin{array}{l}-0.046 \\
(0.048) \\
\end{array}$ \\
\hline Constant & $\begin{array}{c}3.825^{\star * *} \\
(0.191) \\
\end{array}$ & $\begin{array}{c}3.169^{* * *} \\
(0.249) \\
\end{array}$ & $\begin{array}{c}3.824^{* * *} \\
(0.230) \\
\end{array}$ & $\begin{array}{c}3.443^{* * *} \\
(0.588) \\
\end{array}$ \\
\hline Obs. & 696 & 696 & 696 & 696 \\
\hline Cross-sections & 24 & 24 & 24 & 24 \\
\hline Fixed effect & Yes & Yes & Yes & Yes \\
\hline
\end{tabular}

Source: own

Note: Standard errors are in parenthesis; ${ }^{* * *} p<0.01,{ }^{* *} p<0.05,{ }^{*} p<0.1$.

implies that improving ratings bring financial services to be more accessible, deep, and efficient. Among control variables, the results are not much different from earlier estimation. Across both robust alternative estimators, the variation explained in financial market sub-dimensions is documenting differences in magnitude, which may be attributable to the differences in estimation mechanism. For example, using FGLS, and Driscoll Kraay, the variation in coefficients is substantially different, but, interestingly, depth appears to be most sensitive to changes in SCRS. At contrary access though being influences significantly across both estimators, the effect is least relative to other dimensions. Efficiency seems to be moving on the same pattern across two estimators.

Similarly, the difference of robustness of the other variables (i.e. INV, TRO, E.G., INF and D.C.) with the two difference estimators (i.e., FGLS and Driscoll-Kraay) can be seen below in Tab. 6. The possible reason is due to bad E.G., INF and D.C., which brings risks to other comprehensive variables. It can increase trade, symbolizing economic growth, trade opening and bank development. Overall assessments provide us with the macro picture; that is, the performance of financial markets is strongly impacted by SCR, where FD_FMA is an exception.

\section{Discussion}

Our results shown demonstrates that the regression variables do not have variations in the SCR. SCR has a direct and substantial impact on financial markets' performance except for financial markets access, and all other factors are above $50 \%$. Rosati et al. (2020) conclude their research with similar results. They state that SCR is an essential factor for security prices in stock exchanges. On the contrary, study made by Trabelsi and Hmida (2019) showed that there is no impact of SCR on Eurozone stock markets. The inflation coefficients of all Asian countries are negative. Since Maite and Miguel (2018) research has taken inflation as a crucial indicator by demonstrating the importance of SCR to potential inflation, the investments' increase will help better serve their financial 
Tab. 6: Robustness: alternative estimator (sub-dimensions)

\begin{tabular}{|c|c|c|c|c|c|c|}
\hline \multirow{3}{*}{ Variables } & (1) & (2) & (3) & (4) & (5) & (6) \\
\hline & \multicolumn{3}{|c|}{ FGLS } & \multicolumn{3}{|c|}{ Driscoll-Kraay } \\
\hline & FD_FMA & FD_FMD & FD_FME & $F D \_F M A$ & $F D \_F M D$ & $F D \_F M E$ \\
\hline$S C R S_{i t}$ & $\begin{array}{c}0.131^{\star \star \star} \\
(0.033)\end{array}$ & $\begin{array}{l}1.045^{\star \star \star} \\
(0.046) \\
\end{array}$ & $\begin{array}{c}0.753^{\star \star *} \\
(0.080)\end{array}$ & $\begin{array}{l}0.422^{\star *} \\
(0.157) \\
\end{array}$ & $\begin{array}{c}0.844^{\star * *} \\
(0.111)\end{array}$ & $\begin{array}{l}0.757^{\star *} \\
(0.290) \\
\end{array}$ \\
\hline$I N V_{i t}$ & $\begin{array}{c}0.030 \\
(0.063) \\
\end{array}$ & $\begin{array}{c}0.044 \\
(0.073) \\
\end{array}$ & $\begin{array}{c}-0.221^{*} \\
(0.116)\end{array}$ & $\begin{array}{l}-0.041 \\
(0.102) \\
\end{array}$ & $\begin{array}{l}-0.124 \\
(0.125) \\
\end{array}$ & $\begin{array}{l}-0.229 \\
(0.176) \\
\end{array}$ \\
\hline$T R O_{i t}$ & $\begin{array}{c}0.085^{\star * *} \\
(0.020)\end{array}$ & $\begin{array}{c}0.130^{\star * *} \\
(0.027)\end{array}$ & $\begin{array}{c}0.258^{* * *} \\
(0.043)\end{array}$ & $\begin{array}{c}0.069^{* \star *} \\
(0.021)\end{array}$ & $\begin{array}{c}0.163^{* * *} \\
(0.046)\end{array}$ & $\begin{array}{c}0.148^{* * *} \\
(0.040)\end{array}$ \\
\hline$E G_{i t}$ & $\begin{array}{l}-0.026 \\
(0.016) \\
\end{array}$ & $\begin{array}{c}-0.055^{\star \star *} \\
(0.016)\end{array}$ & $\begin{array}{c}-0.063^{\star * *} \\
(0.024)\end{array}$ & $\begin{array}{l}-0.017 \\
(0.017) \\
\end{array}$ & $\begin{array}{c}-0.067^{\star *} \\
(0.028)\end{array}$ & $\begin{array}{l}-0.025 \\
(0.024) \\
\end{array}$ \\
\hline$I N F_{i t}$ & $\begin{array}{l}-0.003 \\
(0.014)\end{array}$ & $\begin{array}{c}-0.043^{* * *} \\
(0.017)\end{array}$ & $\begin{array}{c}-0.091^{* * *} \\
(0.026)\end{array}$ & $\begin{array}{l}-0.011 \\
(0.015)\end{array}$ & $\begin{array}{c}-0.049^{*} \\
(0.024)\end{array}$ & $\begin{array}{c}-0.052^{* *} \\
(0.019)\end{array}$ \\
\hline$D C_{i t}$ & $\begin{array}{l}-0.027 \\
(0.023) \\
\end{array}$ & $\begin{array}{c}-0.076^{\star \star *} \\
(0.029)\end{array}$ & $\begin{array}{c}-0.230^{* * *} \\
(0.044)\end{array}$ & $\begin{array}{c}-0.085^{\star \star *} \\
(0.025)\end{array}$ & $\begin{array}{c}-0.074^{*} \\
(0.041)\end{array}$ & $\begin{array}{l}-0.033 \\
(0.049) \\
\end{array}$ \\
\hline Constant & $\begin{array}{c}3.109^{* * *} \\
(0.271) \\
\end{array}$ & $\begin{array}{l}-0.267 \\
(0.330) \\
\end{array}$ & $\begin{array}{c}1.749^{* * *} \\
(0.543)\end{array}$ & $\begin{array}{c}1.556^{* * *} \\
(0.536)\end{array}$ & $\begin{array}{c}0.569 \\
(0.463) \\
\end{array}$ & $\begin{array}{c}0.529 \\
(1.058)\end{array}$ \\
\hline Obs. & 696 & 696 & 696 & 696 & 696 & 696 \\
\hline Cross-sections & 24 & 24 & 24 & 24 & 24 & 24 \\
\hline Fixed effect & Yes & Yes & Yes & Yes & Yes & Yes \\
\hline
\end{tabular}

Note: Standard errors are in parenthesis; ${ }^{* *} p<0.01,{ }^{* *} p<0.05,{ }^{*} p<0.1$.

markets. Inflation is also closely related to Trade Openness. The degree of openness in trade indicates an increase in foreign exchange reserves. All financial factors in Asian countries have a statistical significance of $5 \%$ considering Trade Openness because they all have positive coefficients.

In many of the arguments that evaluated SCR in the financial market, most critics focused on sovereign credit ratings' political bias. At the same time, the macroeconomic determinants are not as good as the rating agencies said. For example, the downgrading of SCR has an asymmetric impact on the stock market relative to bank ratings (due to rating agencies' SCR policy). The banking sector (banking development) that serves companies and government departments in domestic and international activities plays a vital role in the credibility of Asian countries. Therefore, banking development is aimed at enhancing financial market development index. Comparing the study of Li et al. (2019), where C.R. shows that the effects of upgrade and downgrade are not equal. Their asymmetry discovery is a valuable supplement to the financial market literature. The most relevant studies (and related variables) in European and Asian contexts, such as, e.g., Bales and Malikane (2020), Drago and Gallo (2017), Huang et al. (2018), Treepongkaruna (2012), also show that SCR has a positive effect on financial market development index and plays a crucial role in financial up-gradation or degradation. These studies rely heavily on event research methods to capture C.R.'s short-term impact on financial market indicators. Still, most of the previous research studied the short-term impact of the changes in the SCRS revealed the long-term impact and implications. The same conclusion made Kang and Ming (2016) in the case of East Asia countries. Our results confirm the importance of factors in growth decisions, such as investment (usually subdivided into private investment and public investment) and trade openness. The cited literature discusses economic growth showing several factors simulated to enhance economic growth 
consider the long terms effects. On the contrary, with a careful analysis of short-run investments. Our results show that SCRS can help citizens of Asian economies to obtain better financial services provided in each economy and can also deepen financial services and improve their efficiencies. Similar to the analysis results discussed in the literature, these three elements, namely access, depth, and efficiency, are positively correlated and are very effective for sovereign credit ratings. According to the results, financial market development index has a statistically significant relationship with the sovereign credit ratings of Asian economies. The inflation harms the SCR of these countries, which is similar to the finding of Aras and Öztürk (2018). The inflation coefficient is negative, which means that if inflation increases, the rating falls consistent with theory. However, macroeconomic variables, such as economic growth and trade openness, are also very important. These variables play an important role in improving efficiency, so extra care must be taken. This shows criticism of the decisions of the credit rating agencies is biased.

This study contributes to the area of financial market modeling, in particular the portfolio diversification, considering the risk transmitted by the SCR announcement. The findings may be useful for domestic and global investors to optimize their investment portfolios by understanding the systemic risk which triggers in the Asian financial markets through unfavorable SCR announcements. It may also provide little insight to speculate across the financial markets relative to the counterpart regions.

\section{Conclusions}

The financial markets have become competitive by efficient transfer of valuable information through security prices, which results as a consequence of confidence booster for potential investors (foreign/local) to be actively involved in financial transactions. On the other hand, the financial market does not like asymmetric information, and uncertainty, which not only confines the financial activities, but also results in loss of investors' faith. In this context, the risk-averse investors with a long-term investment horizon, seek to find a relatively safe haven. Sovereign credit rating announcements bring uncertainty to the financial markets, particularly in case of downgrade announcements.
Literature to date is confined to the event study approach, where the short-term impact of such an announcement is modeled by dividing the time into two windows (pre-, and postannouncement) to identify the abnormal return. The present article departs from the traditional event study approach by converting the rating grades into numeric scores to estimate the linear association under robust estimators that correct/cluster the standard error issues, which are often overlooked in related literature. Considering the pivotal economic role of financial markets, and evolving implications due to sovereign credit rating announcements, this study aims to model the role of sovereign credit rating announcements by Standard and Poor's, and Moody's on financial market development of 14 economies of the Asian region. The use of Driscoll Kraay's robust estimator reveals that improving sovereign credit rating score enhances the financial market development in the region, and negative outlook does otherwise. This implies that a sovereign credit rating downgrade announcement gives birth to uncertainty, which curtails the velocity of financial activities. Consequently, the investor finds alternative avenues to shift their investment as a safe haven. Moreover, we also apply several robustness checks, such as alternative estimators: FGLS (Beck \& Katz, 1995), White (1980), Rogers (1993), FamaMacBeth (1973), and Driscoll Kraay (1998), alternative measures (Moody's), and three subdimensions of financial market development. According to the findings from these robustness checks, the positive impact of sovereign credit ratings on financial market development in the region is robust. Thus, this study utilizes the credit ratings announced by Standard and Poor's, and Moody's concerning selected 24 Asian economies/territories. Considering each of the individual economies of the region may provide useful input to the potential investors to diversify their investment by speculating their position (long/short) at micro-level. Therefore, we propose a micro-level extension of the present model, to come up with individual country-specific policy input.

The research has some limitations. Firstly, the study is focused on Asian economies. The dependences in the rest of the world are not included. Secondly, only selected economic indicators were analyzed, and aligned with Li et al. (2019). Third, only Moody's and 
Standard \& Poor's agencies were selected for analysis, while Fitch SCR was not tested as an alternative measure of SCR due to nearly homogenous numeric score as to Standard \& Poor's. Lastly, the possible interaction between the rating agencies has not been analyzed. As competitors can react to each other decisions. This piece of research gives valuable insight at macro-level using Moody's and Standard \& Poor's SCR announcements; however, further research may beneficial for micro-level policy input if the local credit rating announcements maintained by each of the agencies of individual economy/territory may be tested.

Acknowledgment: The project was funded under the program of the Minister of Science and Higher Education titled "Regional Initiative of Excellence" in 2019-2022, project number 018/RID/2018/19, the amount of funding PLN $10,788,423.16$.

\section{References}

Adelino, M., \& Ferreira, M. A. (2016). Bank Ratings and Lending Supply: Evidence from Sovereign Downgrades. Review of Financial Studies, 29(7), 1709-1746. https://doi. org/10.1093/rfs/hhw004

Afonso, A., Gomes, P., \& Rother, P. (2011). Short and long run determinants of sovereign debt credit ratings. International Journal of Finance \& Economics, 16(1), 1-15. https://doi. org/10.1002/ijfe.416

Altavilla, C., Pagano, M., \& Simonelli, S. (2017). Bank Exposures and Sovereign Stress Transmission. Review of Finance, 21(6), 21032139. https://doi.org/10.1093/rof/rfx038

Amstad, M., \& Packer, F. (2015). Sovereign ratings of advanced and emerging economies after the crisis. BIS Quarterly Review, 77-91. Retrieved from https://www.bis.org/publ/qtrpdf/r_qt1512h.pdf

Andritzky, J. R., Bannister, G. J., \& Tamirisa, N. T. (2007). The impact of macroeconomic announcements on emerging market bonds. Emerging Markets Review, 8(1), 20-37. https://doi.org/10.1016/j.ememar.2006.05.001

Aras, O. N., \& Öztürk, M. (2018). The Effects of the Macroeconomic Determinants on Sovereign Credit Rating of Turkey. Journal of Management, Economics, and Industrial Organization, 2(2), 62-75. https://doi. org/10.31039/jomeino.2018.2.2.5

Bales, K., \& Malikane, C. (2020). The effect of credit ratings on emerging market volatility.
Journal of International Financial Markets, Institutions and Money, 65, 101186. https://doi. org/10.1016/j.intfin.2020.101186

Beck, N., \& Katz, J. N. (1995). What To Do (and Not to Do) with Time-Series Cross-Section Data. American Political Science Review, 89(3), 634-647. https://doi. org/10.2307/2082979

Bissoondoyal-Bheenick, E., \& Brooks, R. (2015). The credit risk-return puzzle: Impact of credit rating announcements in Australia and Japan. Pacific-Basin Finance Journal, 35(A), 37-55. https://doi.org/10.1016/j. pacfin.2014.09.001

Böninghausen, B., \& Zabel, M. (2015). Credit ratings and cross-border bond market spillovers. Journal of International Money and Finance, 53(C), 115-136. https://doi. org/10.1016/j.jimonfin.2014.12.007

Borensztein, E., Cowan, K., \& Valenzuela, P. (2013). Sovereign ceilings "lite"? The impact of sovereign ratings on corporate ratings. Journal of Banking \& Finance, 37(11), 4014-4024. https://doi.org/10.1016/j.jbankfin.2013.07.006

Bremer, M., \& Pettway, R. H. (2002). Information and the market's perceptions of Japanese bank risk: Regulation, environment, and disclosure. Pacific-Basin Finance Journal, 10(2), 119-139. https://doi.org/10.1016/S0927538X(01)00033-6

Chen, S.-S., Chen, H.-Y., Chang, C.-C., \& Yang, S.-L. (2016). The relation between sovereign credit rating revisions and economic growth. Journal of Banking and Finance, 64(C), 90-100. https://doi.org/10.1016/j. jbankfin.2015.10.012

Chodnicka-Jaworska, P. (2017). Macroeconomic aspects of banks' credit ratings. Equilibrium. Quarterly Journal of Economics and Economic Policy, 12(1), 101-120. https:// doi.org/10.24136/eq.v12i1.6

Creighton, A., Gower, L., \& Richards, A. J. (2007). The impact of rating changes in Australian financial markets. Pacific-Basin Finance Journal, 15(1), 1-17. https://doi. org/10.1016/j.pacfin.2006.04.003

Cubas-Díaz, M., \& Martínez Sedano, M. Á. M. (2018). Do credit ratings take into account the sustainability performance of companies? Sustainability, 10(11), 4272. https://doi. org/10.3390/su10114272 
De Souza Murcia, F. C., Murcia, F. D.-R., \& Borba, J. A. (2013). The Informational Content of Credit Ratings in Brazil: An Event Study. Brazilian Review of Finance, 11(4), 503-526. https://doi.org/10.12660/rbfin.v11n4.2013.9264

Drago, D., \& Gallo, R. (2017). The impact of sovereign rating changes on European syndicated loan spreads: The role of the ratingbased regulation. Journal of International Money and Finance, 73(Part A), 213-231. https://doi.org/10.1016/j.jimonfin.2017.02.029

Driscoll, J. C., \& Kraay, A. C. (1998). Consistent Covariance Matrix Estimation with Spatially Dependent Panel Data. Review of Economics and Statistics, 80(4), 549-560. https://doi.org/10.1162/003465398557825

Dvorský, J., Petráková, Z., \& Polách, J. (2019). Assessing the Market, Financial, and Economic Risk Sources by Czech and Slovak SMEs. International Journal of Entrepreneurial Knowledge, 7(2), 30-40. https://doi. org/10.37335/ijek.v7i2.91

Endress, T. (2018). "Deliberated Intuition" in Stock Price Forecasting. Economics and Sociology, 11(3), 11-27. https://doi. org/10.14254/2071-789X.2018/11-3/1

Fama, E. F., \& Macbeth, J. D. (1973). Risk, Return, and Equilibrium: Empirical Tests. Journal of Political Economy, 81(3), 607-636.

Filardo, A. (2011). The Impact of the International Financial Crisis on Asia and the Pacific: Highlighting Monetary Policy Challenges from an Asset Price Bubble Perspective (Working Papers, No. 356). Basel: Bank for International Settlements.

Fitch. (2014). Rating Criteria (Technical Report). New York, NY: Fitch Rating.

Galletta, S., \& Mazzù, S. (2019). Liquidity Risk Drivers and Bank Business Models. Risks, 7(3), 89. https://doi.org/10.3390/risks7030089

Gärtner, M., Griesbach, B., \& Jung, F. (2011). PIGS or lambs? The European sovereign debt crisis and the role of rating agencies. International Advances in Economic Research, 17(3), 288-299. https://doi. org/10.2139/ssrn.1816582

Gavurova, B., Ivankova, V., Rigelsky, M., \& Přívarová, M. (2020). Relations Between Tourism Spending and Global Competitiveness - an Empirical Study in Developed OECD Countries. Journal of Tourism and Services, 21(11), 38-54. https://doi.org/10.29036/jots.v11i21.175

Gilchrist, S., Sim, J., \& Zakrajšek, E. (2014). Uncertainty, Financial Frictions, and Investment
Dynamics (Working paper 20038). Cambridge, MA: National Bureau of Economic Research. https://doi.org/10.3386/w20038

Gospodarchuk, G., \& Suchkova, E. (2019). Financial stability: problems of inter-level and cross-sectoral equilibrium. Equilibrium. Quarterly Journal of Economics and Economic Policy, 14(1), 53-79. https://doi.org/10.24136/eq.2019.003

Gulzar, S., Mujtaba Kayani, G., Xiaofeng, H., Ayub, U., \& Rafique, A. (2019). Financial cointegration and spillover effect of global financial crisis: A study of emerging Asian financial markets. Economic Research Ekonomska Istraživanja, 32(1), 187-218. https:// doi.org/10.1080/1331677X.2018.1550001

Hammoudeh, S., Sari, R., Uzunkaya, M., \& Liu, T. (2013). The dynamics of BRICS's country risk ratings and domestic stock markets, U.S. stock market and oil price. Mathematics and Computers in Simulation, 94(1), 277-294. https://doi.org/10.1016/j.matcom.2012.01.002

Heller, J., \& Warzala, R. (2019). The Effects of Entering the Eurozone on other Central and Eastern European Countries in Relation to Poland. Journal of Competitiveness, 11(1), 5-21. https://doi.org/10.7441/joc.2019.01.01

Hoechle, D. (2007). Robust standard errors for panel regressions with cross-sectional dependence. The Stata Journal, 7(3), 281-312. https://doi.org/10.1177/1536867X0700700301

$\mathrm{Hu}, \mathrm{H}$., Kaspereit, T., \& Prokop, J. (2016). The information content of issuer rating changes: Evidence for the $\mathrm{G} 7$ stock markets. International Review of Financial Analysis, 47, 99-108. https://doi.org/10.1016/j. irfa.2016.06.012

Huang, B., He, L., Xiong, S., \& Zhang, Y. (2018). The impact of bond rating downgrades on common stock prices in China. Economic and Political Studies, 6(2), 209-220. https://doi. org/10.1080/20954816.2018.1463602

Hussain, H. I., Abidin, I. S. Z., Kamarulzaman, R., \& Shawtari, F. A. (2018). The impact of state affiliated directors on the capital structure speed of adjustment in an emerging markets. Polish Journal of Management Studies, 18(1), 133-148. https:// doi.org/10.17512/pjms.2018.18.1.11

Ismailescu, I., \& Kazemi, H. (2010). The reaction of emerging market credit default swap spreads to sovereign credit rating changes. Journal of Banking \& Finance, 34(12), 2861-2873. https://doi.org/10.1016/j. jbankfin.2010.05.014 
Jorion, P., \& Zhang, G. (2007). Information Effects of Bond Rating Changes: The Role of the Rating Prior to the Announcement. The Journal of Fixed Income, 16(4), 45-59. https://doi.org/10.3905/jfi.2007.683317

Kang, S., \& Min, S. (2016). Effect of the Sovereign Credit Ratings in EastAsia Countries: Evidence from Panel Vector Autoregression. Emerging Markets Finance and Trade, 52(5), 1121-1144. https://doi.org/10.1080/154049 6X.2015.1103122

Kao, Y.-S., Zhao, K., Ku, Y.-C., \& Nieh, C.-C. (2019). The asymmetric contagion effect from the U.S. stock market around the subprime crisis between 2007 and 2010. Economic Research - Ekonomska Istraživanja, 32(1), 2422-2454. https://doi.org/10.1080/133167 7X.2019.1645710

Keat, H. S. (2009). The Global Financial Crisis - Impact on Asia and Policy Challenges Ahead. Paper presented at Asia Economic Policy Conference: Asia \& the Global Financial Crisis October 18-20, 2009. San Francisco, CA: Federal Reserve Bank of San Francisco.

Kim, S.-J., \& Wu, E. (2008). Sovereign credit ratings, capital flows and financial sector development in emerging markets. Emerging Markets Review, 9(1), 17-39. https://doi. org/10.1016/j.ememar.2007.06.001

Kliger, D., \& Sarig, O. (2000). The information value of bond ratings. The Journal of Finance, 55(6), 2879-2902. https://doi. org/10.1111/0022-1082.00311

Khursheed, A., Mustafa, F., Fatima, M., \& Siddique, F. (2018). Entrepreneurial Intentions: Gem Based Emipirical Analysis On The Northern Europe And Asian Countries. International Journal of Entrepreneurial Knowledge, 6(2), 59-70. https://doi.org/10.2478/IJEK-2018-0014

Klimavičiena, A. (2011). Sovereign credit rating announcements and Baltic stock markets. Organizations and Markets in Emerging Economies, 2(1), 51-62. https://doi. org/10.15388/omee.2011.2.1.14289

Li, C., Pervaiz, K., Khan, M. A., Rehman, F. U., \& Oláh, J. (2019). On the Asymmetries of Sovereign Credit Rating Announcements and Financial Market Development in the European Region. Sustainability, 11(23), 6636. https://doi. org/10.3390/su11236636

Li, H., Jeon, B. N., Cho, S.-Y., \& Chiang, T. C. (2008). The impact of sovereign rating changes and financial contagion on stock market returns: Evidence from five Asian countries. Global Finance Journal, 19(1), 46-55. https://doi.org/10.1016/j.gfj.2007.12.001

Lu, Z., Gozgor, G., Huang, M., \& Lau, C. K. M. (2020). The Impact of Geopolitical Risks on Financial Development: Evidence from Emerging Markets. Journal of Competitiveness, 12(1), 93-107. https://doi.org/10.7441/joc.2020.01.06

Mclean, R. D., Zhang, T., \& Zhao, M. (2012). Why does the law matter? Investor protection and its effects on investment, finance, and growth. The Journal of Finance, 67(1), 313-350. https://doi.org/10.1111/j.15406261.2011.01713.x

Michaelides, A., Milidonis, A., Nishiotis, G., \& Papakyriacou, P. (2012). Sovereign debt rating changes and the stock market (CEPR Discussion Paper No. DP8743). Washington, DC: Center for Economic and Policy Research.

Monfort, A., \& Renne, J.-P. (2013). Decomposing Euro-Area Sovereign Spreads: Credit and Liquidity Risks. Review of Finance, 18(6), 2103-2151. https://doi.org/10.1093/rof/ rft049

Muharam, H., Wisnu, M., Arfinto, E. D., \& Najmudin. (2019). Volatility spillovers under difference in the degree of market integration: Evidence from the selected Asian and Eastern European stock markets. Journal of International Studies, 12(1), 134-150. https://doi.org/10.14254/2071-8330.2019/12-1/9

Murcia, F. C. D. S., Murcia, F. D.-R., \& Borba, J. A. (2013). The Informational Content of Credit Ratings in Brazil: An Event Study. Brazilian Review of Finance, 11(4), 503-526. https://doi.org/10.12660/rbfin.v11n4.2013.9264

Norden, L., \& Weber, M. (2004). Informational efficiency of credit default swap and stock markets: The impact of credit rating announcements. Journal of Banking \& Finance, 28(11), 2813-2843. https://doi.org/10.1016/j. jbankfin.2004.06.011

Pelizzon, L., Subrahmanyam, M. G., Tomio, D., \& Uno, J. (2016). Sovereign credit risk, liquidity, and European Central Bank intervention: Deus ex machina? Journal of Financial Economics, 122(1), 86-115. https://doi.org/10.1016/j.jfineco.2016.06.001

Poon, W. P. H., \& Chan, K. C. (2008). An empirical examination of the informational content of credit ratings in China. Journal of Business Research, 61(7), 790-797. https://doi.org/10.1016/j.jbusres.2007.08.001

Pukthuanthong-Le, K., Elayan, F. A., \& Rose, L. C. (2007). Equity and debt market responses 
to sovereign credit ratings announcement. Global Finance Journal, 18(1), 47-83. https:// doi.org/10.1016/j.gfj.2006.10.001

Rogers, W. (1993). Quantile regression standard errors. Stata Technical Bulletin, 2(9).

Rosati, N., Bellia, M., Matos, P. V., \& Oliveira, V. (2020). Ratings matter: Announcements in times of crisis and the dynamics of stock markets. Journal of International Financial Markets, Institutions and Money, 64, 101166. https://doi.org/10.1016/j.intfin.2019.101166

Ruiz-Brunschwig, S., Carrasco, B., Hayashi, T., \& Mukhopadhyay, H. (2011). The Global Financial Crisis: Impact on Asia and Emerging Consensus (South Asia Working Paper Series, No. 3). Mandaluyon: Asian Development Bank. Retrieved from https://www.adb.org/sites/ default/files/publication/28663/impact-asiaand-emerging-consensus.pdf

Sari, R., Uzunkaya, M., \& Hammoudeh, S. (2013). The Relationship Between Disaggregated Country Risk Ratings and Stock Market Movements: An ARDL Approach. Emerging Markets Finance and Trade, 49(1), 4-16. https:// doi.org/10.2753/REE1540-496X490101

Sensoy, A., Eraslan, V., \& Erturk, M. (2016). Do sovereign rating announcements have an impact on regional stock market comovements? The case of Central and Eastern Europe. Economic Systems, 40(4), 552-567. https://doi.org/10.1016/j.ecosys.2016.02.003

Shin, Y., Yu, B., \& Greenwood-Nimmo, M. (2014). Modelling Asymmetric Cointegration and Dynamic Multipliers in a Nonlinear ARDL Framework. In R. C. Sickles, \& W. C. Horrace (Eds.), Festschrift in Honor of Peter Schmidt (pp. 281-314). New York, NY: Springer.

Subaşı, F. Ö. (2008). The effect of sovereign rating changes on stock returns and exchange rates. International Research Journal of Finance and Economics, 20, 46-54.

Teixeira, J. C. A., Silva, F., Fernandes, A., \& Alves, A. (2014). Banks' capital, regulation and the financial crisis. North American Journal of Economics and Finance, 28, 33-58. https://doi. org/10.1016/j.najef.2014.01.002

Trabelsi, M. A., \& Hmida, S. (2019). Impact of the Credit Rating Revision on the Eurozone Stock Markets. Transition Studies Review, 26(1), 3-14. https://doi.org/10.14665/16144007-26-1-001

Treepongkaruna, S., \& Wu, E. (2012). Realizing the volatility impacts of sovereign credit ratings information on equity and currency markets: Evidence from the Asian Financial Crisis. Research in International Business and Finance, 26(3), 335-352. https:// doi.org/10.1016/j.ribaf.2012.01.006

White, H. (1980). A heteroskedasticityconsistent covariance matrix estimator and a direct test for heteroskedasticity. Econometrica: Journal of the Econometric Society, 48(4), 817-838. https://doi. org/10.2307/1912934

Xu, Q., Wang, L., \& Zhu, Y. (2019). The Effect of OFDI Intensity on TFP: The Moderating Role of R\&D. Transformations in Business \& Economics, 18(3C (48C)), 381-393.

Yang, C.-C., Ou, S.-L., \& Hsu, L.-C. J. S. (2019). A Hybrid Multi-Criteria Decision-Making Model for Evaluating Companies' Green Credit Rating. Sustainability, 11(6), 1506. https://doi. org/10.3390/su11061506

Zhao, Y. L., Liu, F. Y., Liu, C. Y., Usman, M., \& Dutta, K. D. (2020). Readability of Annual Report and Inefficient Investment: Evidence from Debt Financing. Transformations in Business \& Economics, 19(1(49)), 166-190. 


\section{Appendix}

\section{Tab. A1: $\quad$ List of Asian countries/territories}

\begin{tabular}{c|l|c|l} 
S. No. & \multicolumn{1}{|c|}{ Country/territory } & S. No. & \multicolumn{2}{c}{ Country/territory } \\
\hline 1 & Azerbaijan & 13 & Lebanon \\
\hline 2 & Bahrain & 14 & Malaysia \\
\hline 3 & China & 15 & Mongolia \\
\hline 4 & Hong Kong SAR, China & 16 & Oman \\
\hline 5 & India & 17 & Pakistan \\
\hline 6 & Indonesia & 18 & Philippines \\
\hline 7 & Israel & 19 & Qatar \\
\hline 8 & Japan & 20 & Saudi Arabia \\
\hline 9 & Jordan & 21 & Singapore \\
\hline 10 & Kazakhstan & 22 & Thailand \\
\hline 11 & South Korea & 23 & United Arab Emirates \\
\hline 12 & Kuwait & 24 & Vietnam \\
\hline
\end{tabular}

Source: https://tradingeconomics.com/

Note: Countries/territories not included in estimation are dropped due to data unavailability/limited observations with respect to sovereign credit rating announcements.

\section{Tab. A2: Credit ratings outlook and score}

\begin{tabular}{|c|c|c|c|}
\hline Standard and Poor's & Moody's & Description & $\begin{array}{c}\text { Trading economics } \\
\text { score }\end{array}$ \\
\hline AAA & Aaa & Prime & 100 \\
\hline $\begin{array}{l}\text { AA+ } \\
\text { AA } \\
\text { AA- }\end{array}$ & $\begin{array}{l}\mathrm{Aa} 1 \\
\mathrm{Aa} 2 \\
\mathrm{Aa} 3\end{array}$ & High grade & $\begin{array}{l}95 \\
90 \\
85\end{array}$ \\
\hline $\begin{array}{c}\text { A+ } \\
\text { A } \\
\text { A- }\end{array}$ & $\begin{array}{l}\text { A1 } \\
\text { A2 } \\
\text { A3 }\end{array}$ & Upper medium grade & $\begin{array}{l}80 \\
75 \\
70 \\
\end{array}$ \\
\hline $\begin{array}{c}\text { BBB+ } \\
\text { BBB } \\
\text { BBB- }\end{array}$ & $\begin{array}{l}\text { Baa1 } \\
\text { Baa2 } \\
\text { Baa3 }\end{array}$ & Lower medium grade & $\begin{array}{l}65 \\
60 \\
55 \\
\end{array}$ \\
\hline $\mathrm{BB}+$ & Ba1 & Non-investment grade & 50 \\
\hline $\begin{array}{l}\mathrm{BB} \\
\mathrm{BB}-\end{array}$ & $\begin{array}{l}\mathrm{Ba} 2 \\
\mathrm{Ba} 3\end{array}$ & Speculative & $\begin{array}{l}45 \\
40\end{array}$ \\
\hline $\begin{array}{c}\mathrm{B}+ \\
\mathrm{B} \\
\mathrm{B}-\end{array}$ & $\begin{array}{l}\text { B1 } \\
\text { B2 } \\
\text { B3 }\end{array}$ & Highly speculative & $\begin{array}{l}35 \\
30 \\
25\end{array}$ \\
\hline $\mathrm{CCC}+$ & Caa1 & Substantial risks & 20 \\
\hline $\mathrm{CCC}$ & Caa2 & Extremely speculative & 15 \\
\hline $\begin{array}{c}\text { CCC- } \\
\text { CC } \\
\text { C }\end{array}$ & $\begin{array}{c}\text { Caa3 } \\
\text { Ca } \\
\text { C }\end{array}$ & In default with little prospect for recovery & $\begin{array}{r}10 \\
5 \\
\end{array}$ \\
\hline D & I & In default & 0 \\
\hline
\end{tabular}

